\title{
A - METHOD OF DISTRIBUTING BETA-RADIATION TO THE RETICULO-ENDOTHELIAL SYSTEM AND
} ADJACENT TISSUES ${ }^{1}$

\author{
BY HARDIN B. JONES, CHARLES J. WROBEL, AND WILLIAM R. LYONS \\ (From the Division of Medical Physics of the Department of Physics and the Division of Anatomy \\ of the Medical School, University of California, Berkeley)
}

(Received for publication April 3, 1944)

In this study, an attempt has been made to measure the accumulation and retention of radioactive particulate matter by macrophages, and to determine the effects of various levels of $\beta$-radiation from phosphorus upon these cells and the tissues intimately associated with them. Quantitative studies of phagocytosis (1 to 4), and phagocytosis of radioactive material have received some attention (5 to 11), but as far as we are aware, this study is the first in which a substance emitting only $\beta$-radiation has been distributed to the reticulo-endothelial system and its effects noted. Recently, radio-bromine has been used in synthesizing radioactive di-brom trypan blue and the distribution of this compound studied after injection into rabbits and mice $(5,7)$.

\section{PREPARATION OF RADIOACTIVE CHROMIC PHOSPHATE}

Anhydrous chromic phosphate has been used in this study because of its inertness and apparent lack of toxic effect; it is easily prepared in a fine and even suspension of particles, $1 \mu$ or less in diameter. Radicactive phosphorus ( $P^{x}$ ) was obtained as a solution of di-sodium phosphate with non-radioactive phosphorus carrier. An equivalent amount of sodium bicarbonate and chromic nitrate solution in excess was added. The freshly precipitated salt was a crystalline hydrate, readily soluble in hot water, acids, or bases. This was centrifuged, washed, and recentrifuged. After complete drying at $110^{\circ} \mathrm{C}$., the product was heated to $600^{\circ} \mathrm{C}$. in the electric furnace. This final treatment resulted in a dark brown, amorphous powder, insoluble in strong acid or alkali, or in aqua regia. The product was transferred to a $50 \mathrm{ml}$. serum bottle, half filled with pyrex beads. A suitable quantity of isotonic glucose solution was added ( 1 to $2 \mathrm{ml}$. per 100 mgm.) and the bottle autoclaved. Rotation of the bottle in a mill for $\mathbf{1 2}$ hours, at a speed which allowed the beads to cascade down the sides, resulted in a preparation

1 Partial support of this work was provided by the Columbia Fund for Medical-Physics. (Columbia Foundation). suitable for intravenous administration. The final product has the appearance of thin clay mud.

Another method of preparing the chromic phosphate has been used recently; it gave better precipitation of the phosphorus: Every volume of $0.1 \mathrm{~N} \mathrm{Na} \mathrm{HPO}_{4}$ was mixed with one volume of $0.5 \mathrm{~N} \mathrm{Cr}\left(\mathrm{NO}_{3}\right)_{2}$ and one-third volume of $1.0 \mathrm{~N} \mathrm{NaAc}$. The crystalline hydrate obtained was treated as above.

\section{EXPERIMENT I}

Two groups of mice were used to obtain information regarding the uptake and retention of chromic phosphate and the effects of its $\beta$-radiation.

In Group $A, 12$ female Swiss mice received varying doses of radicactive chromic phosphate via the tail vein, and were allowed varying survival periods (Table I).

In Group B, 16 female Swiss mice, divided into 4 groups, were injected through the tail vein with $3.4 \mathrm{mgm}$. of chromic phosphate, suspended in $0.25 \mathrm{ml}$. of isotonic glucose. All of the animals received the same weight of salt, but the samples were so prepared that the radioactivity in each sample varied. Thus, Group 1 received 70.8 microcuries per mouse; Group 2, 39.4 microcuries; Group 3, 18.2 microcuries; and Group 4, 4.25 microcuries. Two animals from each group were sacrificed after 3 days and the remainder after $\mathbf{5}$ days, with $\mathbf{2}$ control animals for each period.

Samples of spleen, liver, and lung were taken from mice 6 to 12 (Table I) for radioactive and histologic examination while in mice 1 to 5 , only the liver was examined radioactively. Tissue samples of 20 to $150 \mathrm{mgm}$. wet weight were taken for radiologic analysis on a $\beta$-sensitive Geiger counter tube and the Lauritsen electroscope (14). Results listed in Table I were calculated as percentage of the dose recovered in each tissue; for comparing the activity in different organs, percentage of recovery per gram is also given.

There are several difficulties attending the conversion of internal $\beta$-radiation to comparable roentgen ( $r$ ) values. A large block of tissue, in which one microcurie of radioactive phosphorus is distributed uniformly in each gram of tissue, absorbs 3,550 ergs per gram of tissue per day. This is equivalent to $42 \mathrm{r}$ of $\mathrm{x}$-rays (12). From a given source in an aqueous media, about 48 per cent of $\beta$ radiations of $\mathrm{P}^{2}$ are absorbed in each $0.1 \mathrm{~cm}$. distance traversed.2 Since the mouse liver and spleen are only $\mathbf{0 . 2}$

\footnotetext{
2 From $P^{\infty} \beta$-ray absorption curves with aluminum (13).
} 
TABLE I

Group A-12 mice receiving varying doses of radioactive chromic phosphate

\begin{tabular}{|c|c|c|c|c|c|c|c|c|c|c|c|c|c|c|c|}
\hline \multirow[b]{2}{*}{$\begin{array}{c}\text { Ani- } \\
\text { mal } \\
\text { num- } \\
\text { ber }\end{array}$} & \multirow[b]{2}{*}{$\begin{array}{c}\text { Body } \\
\text { weight }\end{array}$} & \multirow[b]{2}{*}{$\begin{array}{c}\text { Duration } \\
\text { of } \\
\text { experiment }\end{array}$} & \multirow[b]{2}{*}{$\begin{array}{l}\text { Final } \\
\text { body } \\
\text { weight }\end{array}$} & \multicolumn{3}{|c|}{ Chromic phosphate } & \multicolumn{3}{|c|}{ Liver } & \multicolumn{3}{|c|}{ Spleen } & \multicolumn{3}{|c|}{ Lung } \\
\hline & & & & \begin{tabular}{|c|} 
Volume \\
of \\
dose
\end{tabular} & & & $\begin{array}{c}\text { Uptake } \\
\text { per } \\
\text { gram } \\
\text { of } \\
\text { tissue }\end{array}$ & \begin{tabular}{|l} 
Uptake \\
whole \\
organ
\end{tabular} & $=\begin{array}{c}\text { Total } \\
\text { rt } \\
\text { accu- } \\
\text { mulated }\end{array}$ & $\mid \begin{array}{c}\text { Uptake } \\
\text { per } \\
\text { gram } \\
\text { of } \\
\text { tissue }\end{array}$ & $\begin{array}{c}\text { Uptake } \\
\text { whole } \\
\text { organ }\end{array}$ & $\begin{array}{c}\text { Total } \\
\text { rf } \\
\text { accu- } \\
\text { mulated }\end{array}$ & $\begin{array}{c}\text { Uptake } \\
\text { per } \\
\text { gram } \\
\text { of } \\
\text { tissue }\end{array}$ & $\begin{array}{l}\text { Uptake } \\
\text { whole } \\
\text { organ }\end{array}$ & $\begin{array}{c}\text { Total } \\
\text { rf } \\
\text { accu- } \\
\text { mulated }\end{array}$ \\
\hline $\begin{array}{r}1 \\
2 \\
3 \\
4 \\
5 \\
6 \\
7 \\
8 \\
9 \\
10 \\
11 \\
12\end{array}$ & $\begin{array}{l}18.0 \\
21.5 \\
24.0 \\
23.0 \\
20.5 \\
20.5 \\
20.0 \\
21.5 \\
20.5 \\
24.0 \\
22.5\end{array}$ & $\begin{array}{r}24 \text { hours } \\
24 \text { hours } \\
24 \text { hours } \\
24 \text { hours } \\
108 \text { hours } \\
30 \text { days } \\
10 \text { days } \\
15 \text { days } \\
15 \text { days } \\
5 \text { days } \\
23 \text { days } \\
23 \text { days }\end{array}$ & \begin{tabular}{|l|}
18.0 \\
21.5 \\
24.0 \\
23.0 \\
20.0 \\
16.0 \\
19.0 \\
21.0 \\
20.0 \\
18.0 \\
17.0
\end{tabular} & $\begin{array}{c}m l . \\
0.10 \\
0.10 \\
0.10 \\
0.10 \\
0.50 \\
0.50 \\
0.50 \\
0.25 \\
0.25 \\
0.25 \\
0.25 \\
0.25\end{array}$ & \begin{tabular}{|c|}
$m g m$. \\
0.26 \\
0.26 \\
0.26 \\
0.26 \\
1.3 \\
1.3 \\
20.0 \\
10 \\
10 \\
10 \\
10 \\
10
\end{tabular} & $\begin{array}{c}\begin{array}{c}\text { micro. } \\
\text { curies* }\end{array} \\
3.75 \\
3.75 \\
3.75 \\
3.75 \\
18.8 \\
18.8 \\
230 \\
115 \\
115 \\
265 \\
265 \\
265\end{array}$ & $\begin{array}{r}\text { per } \\
\text { cent } \\
99 \\
72 \\
140 \\
63 \\
83 \\
90 \\
78 \\
57 \\
61 \\
70 \\
70 \\
77\end{array}$ & $\begin{array}{l}81 \\
59 \\
65 \\
77 \\
69 \\
67 \\
72\end{array}$ & $\begin{array}{r}4,270 \\
39,800 \\
20,800 \\
22,200 \\
24,500 \\
52,300 \\
57,500\end{array}$ & $\begin{array}{l}49 \\
50^{* *} \\
54^{* *} \\
58^{* *} \\
98^{* *} \\
60^{* *} \\
50^{* *}\end{array}$ & \begin{tabular}{|r|}
4.3 \\
4.9 \\
6.2 \\
7.0 \\
11.7 \\
13.1 \\
14.7
\end{tabular} & $\begin{array}{r}1,140 \\
9,650 \\
9,000 \\
9,300 \\
15,800 \\
20,200 \\
17,000\end{array}$ & \begin{tabular}{|r|}
15.7 \\
6.3 \\
9.0 \\
8.0 \\
7.2 \\
12.1 \\
33.5
\end{tabular} & \begin{tabular}{|l|}
2.6 \\
0.63 \\
1.4 \\
1.9 \\
1.3 \\
2.7 \\
6.6
\end{tabular} & $\begin{array}{r}88 \\
1,470 \\
1,500 \\
1,330 \\
2,070 \\
3,950 \\
11,300\end{array}$ \\
\hline
\end{tabular}

* Microcuries with uranium $X_{2}$ standard $=3.7 \times 10^{4}$ primary $\beta$-particles per second.

* Based on an estimated normal spleen weight of $120 \mathrm{mgm}$; observed weight, 7 to $13 \mathrm{mgm}$.

$\uparrow$ Died. f In $\beta$-radiation (see text).

to $0.6 \mathrm{~cm}$. thick, an appreciable and varying portion of the $\beta$-rays will be absorbed outside the liver and spleen. A graphic model of the liver elliptically shaped $(2.9,2.6 \mathrm{~cm}$. diameters) and $0.60 \mathrm{~cm}$. thick in the middle tapered to the edge, gave an average distance of $0.2 \mathrm{~cm}$. traversed by $\beta$-particles of internally produced $\beta$-radiation. The thin periphery of the liver and the spleen will absorb less (20 to 50 per cent). Near the center of the liver, the energy absorbed will be close to 90 per cent or $38 \mathrm{r}$ per microcurie per gram of tissue per day (Figure 1). The liver on the average will receive $42 \times 0.73=30.7 \mathrm{r}$ per microcurie per gram of tissue per day. Estimation of the spleen is more difficult because of its variation in size and also in position with respect to the liver. A conservative estimate for the spleen and lungs is $\mathbf{3 0}$ to $\mathbf{5 0}$ per cent self-absorption. The $r$ values in Table $I$ and in the text are based upon the constants: $30.7 \mathrm{r}$ per microcurie of $\mathrm{P}^{22}$ per gram of liver per day and $17 \mathrm{r}$ for the lungs and spleen. The values in Table I are corrected for the decay of $P^{n}$ and are accumulated to the termination of each observation.

\section{Results}

None of the mice used in these 2 groups showed untoward symptoms during or after injection. Quantitative measurements of the uptake of the suspension agreed substantially with those obtained by other workers on similar problems $(1,2,9)$. The bulk of the material was found in the liver, with similar quantities per gram of tissue in the spleen. The lungs showed a smaller uptake than these organs. Considerably more chromic phosphate is found in the liver than in the similar case of azo-dye administration (7). In the case of one mouse, allowed to survive 30 days after injection, 81 per cent of the dose administered was retained in the liver.

Livers examined macroscopically always showed varying degrees of color change, depending upon the amount of material administered. The opaque, mud-colored livers are evidence of their chromic phosphate content. Histologic examination of the liver revealed that almost all of its chromic phosphate content could be accounted for in the endothelial cells of the sinusoids. Rarely, a few granules were seen within the hepatic cells. Except for an occasional macrophage showing nuclear pyknosis, none of the cells, even when heavily laden with the chromic phosphate, appeared to be injured. The spleen, on the other hand, showed a reaction in keeping with the known high radiosensitivity of lymphoid tissue. In the animals of Group $B$, splenic weights were found at necropsy to vary inversely as the total dose of radiation administered. In animals 6 to 12 of Group $A$ (Table I), which had received a considerably higher dosage, the spleens were reduced almost to a connective tissue framework and macrophages. $^{3}$ As in the liver, the radioactivity found

A 4.5 kilogram rabbit was given $4 \mathrm{ml}$. of chromic phosphate suspension (total dose 800 microcuries and 60 
in the spleen could be accounted for by the chromic phosphate granules in individual and fused macrophages. Except for the presence of sparsely distributed macrophages bearing chromic phosphate particles, the lungs appeared normal, there being no evidence of parenchymal damage due to the $\beta$-radiation.

All animals which received doses greater than 20 microcuries showed an 80 to 95 per cent decrease in spleen size by the fifth day. The general. loss of weight of Group $A$ animals 7 to 12 is noted in Table I. Animals in this series receiving more than 100 microcuries incurred a 25 per cent weight loss.

\section{EXPERIMENT II}

Five female mice, Group $C$, weight 20 to 23 grams, were injected with a tracer dose of chromic phosphate of $1 \mathrm{mgm}$. in weight. These mice were sacrificed at 5 days and the various tissues were assayed for radioactivity as in Experiment I (Table II).

A female dog, weight $8.5 \mathrm{kgm}$., was given a comparable dose of 30 microcuries and $85 \mathrm{mgm}$. of $\mathrm{CrPO}_{4}$. The dog was sacrificed at the end of 4 days. Liver, spleen, lungs, red bone marrow, lymph nodes, and pituitary were removed whole, weighed, and ashed at $500^{\circ} \mathrm{C}$. Results are tabulated in Table III.

\section{Results}

In the dog and mice, as much as 90 per cent of the total injected chromic phosphate suspension can be recovered from the liver in 4 to 5 days. In both animals, the liver, lungs, and spleen account for the major part (95 to 98 per cent) of the total injected material. An almost

mgm. of chromic phosphate). After 30 days the spleen was examined at biopsy; at that time it was $5 \mathrm{~cm}$. wide and $10 \mathrm{~cm}$. long. By 60 days, no changes in body weight had occurred; there were no macroscopic changes in any abdominal or thoracic viscera, except the spleen. Of the spleen, there remained only a small pencil-shaped sac filled with a little fluid and chromic phosphate.
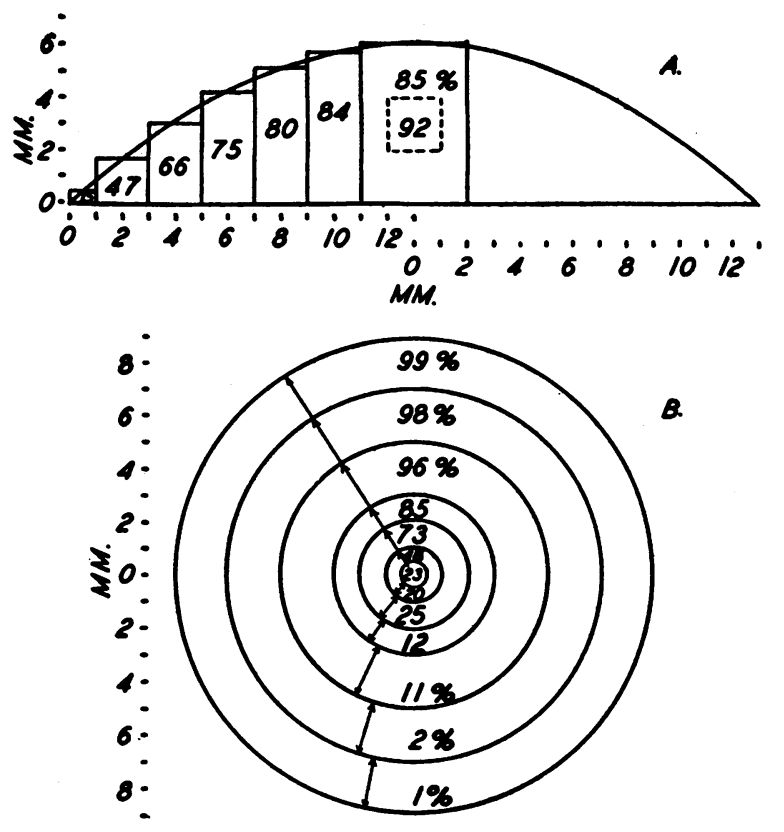

FIG. 1

A. Cross-Section of Whole Mouse Liver (Weight 1.1 grams) Resting on a Flat Surface

The segments are labeled according to the average percentage of radiation absorption by the whole liver of $\beta$-rays originating in that segment.

B. The Concentric Rings Are the Expected Absorption of the $\beta$-RAys at Various RAdII From a PoInt SOURCE

Consider the center of "B" to occur anywhere in " $A$ " and that both have solid dimensions. In the 85 per cent volume in "A," the average of all possible point sources of radiation will travel so that 85 per cent will be absorbed in the liver. It can be determined directly from the diagram that if the " $B$ " is superimposed upon " $A$ " so that the centers of each coincide, then 92 per cent of the effective absorption area of " $B$ " will be covered by " $A$ " (see dotted area in center of "A").

negligible amount is distributed in the other tissues.

In comparison to Group $A$, Table I, there may

TABLE II

Group $C$-Percentage of recovery of $\mathrm{CrPO}_{4}$ per gram of tissue 5 days after $1 \mathrm{mgm}$. dose of $\mathrm{CrPO}_{4}$

\begin{tabular}{c|c|c|c|c|c|c|c|c|c|c|c|c}
\hline \hline $\begin{array}{c}\text { Whole } \\
\text { liver }\end{array}$ & Liver & Lung & Spleen & Femur & $\begin{array}{c}\text { Lymph } \\
\text { nodes }\end{array}$ & Thymus & Kidney & $\begin{array}{c}\text { Salivary } \\
\text { gland }\end{array}$ & $\begin{array}{c}\text { Skin and } \\
\text { subcutaneous } \\
\text { C.T. }\end{array}$ & Blood & Muscle & Intestine \\
\hline 81 & 83 & 37 & 32 & 3.3 & 1.1 & 1.1 & 1.0 & 0.80 & 0.7 & 0.11 & 0.1 \\
85 & 90 & 15 & 49 & 2.3 & 0.6 & & 0.7 & & 0.6 & 0.1 & 0.02 \\
90 & 99 & 26 & 50 & 3.0 & 0.4 & & 0.8 & & 0.6 & 0.1 & \\
91 & 89 & 29 & 45 & 2.7 & 0.5 & & 0.5 & & 0.9 & \\
89 & 92 & 30 & 47 & 1.5 & 1.0 & & 0.9 & & & \\
\hline
\end{tabular}


TABLE III

Recovery of $\mathrm{CrPO}_{4}$ in an $8.5 \mathrm{kgm}$. dog, female; dose $85 \mathrm{mgm}$. and 30 microcuries of $\mathrm{CrPO}_{4}$

\begin{tabular}{|c|c|c|}
\hline Organ & $\begin{array}{c}\text { Recovery per } \\
100 \text { grams of tissue }\end{array}$ & $\begin{array}{l}\text { Recovery per } \\
\text { whole organ }\end{array}$ \\
\hline $\begin{array}{l}\text { Liver } \\
\text { Spleen } \\
\text { Lungs }\end{array}$ & $\begin{array}{c}\text { per cent } \\
29.1 \\
18.4 \\
1.0\end{array}$ & $\begin{array}{c}\text { per cent } \\
90.2 \\
6.3 \\
1.6\end{array}$ \\
\hline $\begin{array}{l}\text { Red bone marrow } \\
\text { Lymph nodes } \\
\text { Pituitary } \\
\text { All others }\end{array}$ & $\begin{array}{l}0.35 \\
0.45 \\
0.26\end{array}$ & $\begin{array}{r}98.1 \\
\ldots \quad 1.9\end{array}$ \\
\hline
\end{tabular}

be some reason for expecting the phagocytic efficiency of the liver to be decreased with the larger dosages of chromic phosphate. The percentage of recovery of a dose of $10 \mathrm{mgm}$. or greater per mouse is lower than that observed with doses of $1 \mathrm{mgm}$. per mouse. This might have been a result of partial blockage of the liver endothelial cells. It is also possible that the greater concentration of the chromic phosphate suspension given to Group $A$ animals 7 to 12 may have resulted in a different particular aggregation pattern of the chromic phosphate when injected into the blood stream.

\section{EXPERIMENT III}

Two more groups of mice were employed in order to obtain information regarding $(1)$ the effects of high levels of $\beta$-radiation, over longer periods of time, and (2) the effects of prolonged retention of large amounts of inert chromic phosphate in the body. In Group $D$, comprising 24 female " $A$ " strain mice, weight 25 to 27 grams, 10 animals were injected intravenously with $9.0 \mathrm{mgm}$. of radioactive chromic phosphate (300 microcuries), 6 with $3.6 \mathrm{mgm}$. (120 microcuries), 5 with $1.8 \mathrm{mgm}$. (60 microcuries), and 3 served as controls. All animals were sacrificed at the end of 3 months. In Group E "A" strain male mice, weight 19 to 23 grams, 12 mice received intravenously $20 \mathrm{mgm}$. of inert (non-radioactive) chromic phosphate and 11 others received $13 \mathrm{mgm}$. Fifteen untreated animals served as controls. Three mice on each level and 3 controls were sacrificed at the end of 3,7 , and' 12 months.

\section{Results}

All but 2 of the animals of Group $D$ appeared in good condition at the end of 3 . months. Growth had continued and the mice appeared normal in every respect. Radioactive analyses were not made, but it was estimated on the basis of data obtained from Experiment I that the mice in Group $D$ on the highest dosage received a minimum of $81,000 \mathrm{r}$ in the liver and spleen and $12,000 \mathrm{r}$ in the lungs. These organs in the mice on the 2 lower dosages of radioactive material received proportionately less irradiation. Since the half-life of the $P^{32}$ used in preparing the chromic phosphate was approximately 14.5 days, only about 1 per cent of the activity could be expected to remain after 3 months.

Histologic examination of the liver revealed that in the 10 animals which had received 300 microcuries in $9.0 \mathrm{mgm}$., much of the chromic phosphate had been retained in the Kupffer cells. In the animals of the $1.8 \mathrm{mgm}$. dose, little or no chromic phosphate could be detected. In all but 2 animals of the 2 groups, the livers appeared normal except for the phagocytized material. These 2 mice which had received the high radioactive dosage showed a yellow tingeing of the skin suggestive of liver damage, and at the end of the experiment, their weights were significantly less than the group average. Necropsy revealed large livers which, on histologic section, were diagnosed as hepatomata. No metastases were found. In several thousand autopsies of mice of this strain, this type of tumor had not previously been encountered.

The spleen of all the animals in Group $D$ (3 months after injection) appeared normal in size and weight, and on microscopic section, it was found that complete restoration to normal organization had occurred after the destructive effects of the radiation had disappeared. The lungs of all animals but one were of normal appearance. The right lung of this animal was capped at the apex by a firm white nodule which, on microscopic examination, was diagnosed as a bronchiogenic carcinoma: No other evidence of neoplasm was found in this animal, and since on 2 subsequent occasions, similar nodules have been found in normal mice, they probably have no relation to the radioactive material injected.

All of the animals of Group $E$ which had received large quantities (13 had $20 \mathrm{mgm}$.) of inert chromic phosphate seemed normal in appearance, growth, weight, and activity. All of the mice when autopsied after 3,7 , and 12 months, respectively, showed chromic phosphate microscopically in the lungs, spleen, and particularly in the Kupffer cells of the liver. Here, 
many of the cells had aggregated into clumps of from 5 to 20 cells in the sinusoids or in the connective tissue surrounding the larger vessels. Lymphoid infiltration was sometimes noted in these perivascular sites and was, in some instances, accompanied by moderate numbers of neutrophilic leukocytes. In one of the livers, areas of definite necrosis were observed, but these were small and replaced in part by connective tissue. Except for the widely scattered deposits of chromic phosphate which could be observed grossly as well as microscopically, the livers seemed to be essentially normal.

\section{DISCUSSION}

The information obtained on the uptake and retention of radioactive phosphorus in the form of an insoluble chromic salt differs strikingly from that gathered in studies on mice in which soluble radioactive phosphorus was given (14). In the latter work, the liver, kidney, and small intestine contained about 9 per cent per gram of tissue and other soft tissues ranged downward to 1 per cent per gram or less. In such cases, the initial activity was quickly dissipated by excretion and interchange with the phosphate stores in the animal. The high degree of retention of radioactive chromic phosphate and the tolerance of the animal to dosages as large as 1 mgm. per gram of body weight indicate that, except for the $\beta$-radiation, the radioactive chromic phosphate is inert. That this retention is partly, if not wholly, attributable to the insolubility of the form of chromic phosphate used seems to follow from the results obtained by Drinker et al. $(1,2)$. These workers believed that the varying degree of retention by the body of different suspensions studied by them was a reflection of their relative solubilities.

The finding of large amounts of the inert chromic phosphate in the spleens and livers of the mice 12 months after injection would suggest that this insoluble material is released slowly from the animal. That it may be released from certain dying or dead macrophages and be

\footnotetext{
- Presence of minute traces of radioactivity in the bile, feces, and urine was detected in animals injected with chromic phosphate of high activity, thus indicating a very slow but continuous excretion via these pathways.
}

phagocytized again by other healthy ones seems likely. However, there is no evidence that it could be "leached out" of the reticulo-endothelial cells and used elsewhere or excreted as readily as when colloidal calcium phosphate is injected $(3,4)$.

No evidence was obtained of any serious damage caused to mice by the retention of the relatively enormous doses of non-radioactive chromic phosphate over a long period of time. In this respect, it can be best compared to carbon ingested by the pulmonary macrophages. The radioactive chromic phosphate, even in low doses, caused rapid involution of the lymphoid elements associated with the reticulo-endothelial cells bearing the radioactive granules, but, as far as could be determined, the liver and lung parenchymal cells escaped damage except in the 2 mice (Experiment III, Group D) receiving the highest dosage of radioactivity ( 300 microcuries). It is not unlikely that the radioactive chromic phosphate was responsible for these 2 tumors and further experiments are now in progress to decide this question.

There may be considerable variation in tolerance to $\beta$-radiation in mice. The 10 mice receiving $\mathbf{3 0 0}$ microcuries in Experiment III lived 3 months in relatively good condition, while mice 11 and 12, receiving 265, died in 23 days.

\section{SUMMARY}

Suspensions of anhydrous chromic phosphate were prepared from both radioactive and nonradioactive phosphorus. The average particle size was 1 micron, and the suspension in isotonic glucose was suitable for intravenous injection.

Chromic phosphate is inert and insoluble in the living tissues. Doses as large as $1 \mathrm{mgm}$. per gram of body weight are tolerated in mice.

Quantitative radioactive determinations of the uptake of intravenously injected radioactive chromic phosphate were made in the mouse and the dog. Approximately 90 per cent of the material was found in the liver. The bulk of the remaining portion was found in the spleen and in the lungs. This agreed with histologic findings.

The chromic phosphate is retained in the endothelial cells of mice for at least 1 year without detected decrement. 
The pattern of phagocytosis of injected chromic phosphate particles brings about a concentration of $\beta$-radiation in the liver and spleen which is of the order of 100 times the concentration in other tissues, except in the lung tissue. In the mouse, however, about 27 per cent of the $\beta$-radiation originating in the liver and spleen is absorbed by adjacent tissues up to $0.60 \mathrm{~cm}$. distance. In larger animals, where the shortest thickness of these organs is $1 \mathrm{~cm}$., relatively little external loss will result.

The lymphoid tissue of the spleen was decidedly sensitive to the radioactive chromic phosphate. Mice that did not die from large doses of $\beta$-radiation showed rapid regeneration of the spleen.

Reticulo-endothelial cells, hepatic and pulmonary epithelium are able to withstand large doses of $\beta$-radiation. However, in 2 mice, primary hepatoma developed and this may have been due to the high dosage of $\beta$-radiation ( $a$ magnitude of an accumulation of $80,000 \mathrm{r}$ in 20 days) in the liver.

\section{BIBLIOGRAPHY}

1. Drinker, C. K., and Shaw, L. A., Quantitative distribution of particulate material (Manganese dioxide) administered intravenously to the cat. J. Exper. Med., 1921, 33, 77.

2. Lund, C. C., Shaw, L. A., and Drinker, C. K., Quantitative distribution of particulate material (Manganese dioxide) administered intravenously to the dog, rabbit, guinea pig, rat, chicken, and turtle. J. Exper. Med., 1921, 33, 231.

3. Gersh, I., Histochemical studies on the fate of colloidal calcium phosphate in the rat. Anat. Rec., 1938, 70, 331.
4. Gersh, I., The fate of colloidal calcium phosphate in the dog. Am. J. Physiol., 1938, 121, 589.

5. Moore, F. D., and Tobin, L. H., Studies with radioactive di-azo dyes. I. The localization of radioactive di-brom trypan blue in inflammatory lesions. J. Clin. Invest., 1942, $21,471$.

6. Tobin, L. H., and Moore, F. D., Studies with radioactive di-azo dyes. II. The synthesis and properties of radioactive di-brom trypan blue and radioactive di-brom Evans blue. J. Clin. Invest., 1943, $22,155$.

7. Moore, F. D., Tobin, L. H., and Aub, J. C., Studies with radioactive di-azo dyes. III. The distribution of radioactive dyes in tumor-bearing mice. J. Clin. Invest., 1943, 22, 161.

8. Pohle, E. A., and Ritchie, G., Histological studies of the liver, spleen and bone marrow in rabbits following intravenous injection of thorium dioxide. Am. J. Roentgenol., 1934, 31, 512.

9. Reeves, R. J., and Morgan, J. E., The retention of thorium dioxide by the reticulo-endothelial system. Radiology, 1937, 29, 612.

10. Radt, P., Eine neue Methode zur röntgenologischen Sichtbarmachung von Leber und Milz durch Injektion eines Kontrastmittels. Med. Klin., 1930, 26, 1888.

11. Selling, L., and Osgood, E. E., The action of benzol, roentgen rays and radioactive substances on the blood and blood-forming tissue. Handbook of Hematology, by Downey, H., Paul B. Hoeber, New York, 1938, Vol. 4, p. 2689.

12. Low-Beer, B. V. A., Lawrence, J. H., and Stone, R. S., The therapeutic use of artificially produced radioactive substances. Radiology, 1942, 39, 573.

13. Wu, Chien-Shiung. The continuous $x$-rays excited by the Beta particles of ${ }_{15} \mathrm{P}^{22}$. Physical Rev., 1941, $59,481$.

14. Jones, H. B., Chaikoff, I. L., and Lawrence, J. H., Phosphorus metabolism of the soft tissues of the normal mouse as indicated by radioactive phosphorus. Am. J. Cancer, 1940, 40, 235. 